\title{
SPHERICAL MICROPARTICLES FROM GOLD-BEARING QUARTZ VEINS OF THE IROKINDA DEPOSIT, WESTERN TRANSBAIKALIA
}

\author{
A. V. Tatarinov'1, L. I. Yalovik1, V. A. Vanin² \\ ${ }^{1}$ Geological Institute, Siberian Branch of RAS, Ulan-Ude, Russia \\ 2 Institute of the Earth's Crust, Siberian Branch of RAS, Irkutsk, Russia
}

\begin{abstract}
We have studied the material composition of ore microparticles extracted from gold concentrates of operating quartz vein No. 30 located in the Irokinda deposit, Western Transbaikalia. We consider the origin of such microparticles in connection with our observation data and the previously published structural and geological features revealed in formation of the ore field, as well as tectonophysical conditions of formation of many gold-bearing quartz veins, including vein No. 30.

Gold-quartz veins, located in the allochthonous plate thrusted onto the Kelyano-Irokinda belt (Fig. 1), infill the NEstriking fault zones. E.A. Namolov conducted the tectonophysical analysis of the "elementary fracture - ore-bearing suture/joint" system, which provided a genetic explanation of the morphology of ore quartz veins (including vein No. 30) and conditions for formation of their host fault zones. Ore-bearing fractures are combinations of shear and cleavage cracks that occur in case of certain positions of the strain ellipsoid in conditions of horizontal compression. Due to repeated intra-mineralization displacements, the texture of the ores is strappy, and the quartz matrix of the veins contains numerous inclusions of host rocks.
\end{abstract}

The spherical particles have zonal structures and consist of metal nodes and external continuous or discontinuous shells, which thickness ranges from 10 to 400 microns (Fig. 2, Fig. 3). The nodes are composed mainly of native Fe with admixtures of $\mathrm{Fe}, \mathrm{Mn}, \mathrm{Al}$ (Table), the contents of which are typically less than 1.0-1.5 wt \%.

Characteristic features of the mineral composition of shells of the spheroidal microparticles:

- The widespread graphite matrix consisting of minerals of different classes, except for native;

- Pyrite in the group of ore oxides of Fe, Mn, $\mathrm{Cr}$, Ti;

- A large group of carbonate minerals;

- Feldspars and natrosilite among silicates;

- The mineral with $\mathrm{CaBr}_{2}$ composition;

- Mono-mineral quartz rims.

The consequence of metamorphism, i.e. deformational or mechano-chemical transformations of rocks in Irokinda, as well as the autochthon (the rock bed of the Kelyano-Irokinda belt), is the gas-water ('hydrothermal') system capable of forming the spherical ore particles with low-temperature mineral rims.

The main feature of the structure of the spherical microparticles in Irokinda is a sharp contrast of the crystallization conditions of the metal nodes and their rims. Similar conditions leading to formation of contrasting mineral associations, that are similar in compositions to the discussed spherules, are characteristic of the gas-water-lithoclastitic and gas-water stages of mud volcanoes. For these stages, we suggest the cavitation mechanism of formation of spherical metal particles of $\mathrm{Fe}, \mathrm{Fe}-\mathrm{Cr}$ and other compositions, which is accompanied by combustion (pyrogenic melt) and pyrolysis of hydrocarbon components of the fluid. This mechanism, with the exception of the origin of the melt (in this case, of the friction type) seems to most closely correspond to the actual data. The spheroids are likely to have formed in the pre-ore stage of formation of the quartz veins.

The high-temperature metal spherical microparticles revealed in our study can be regarded as specific indicators showing conditions in which the ore-forming system of the dynamo-metamorphic type was functioning to produce gold mineralization on the Irokinda deposit. The structure and composition of these microparticles differ from those of the microspherules from other gold deposits in Transbaikalia (black shale formation in Sukhoi Log, and lowsulphide gold-quartz ore formation in Pervenets), which also belong to the dynamogenic genetic type. However, the ore-forming systems of the compared deposits have two common factors that contribute to formation of spherical microparticles - high tectonic activity manifested by repeated (impulse-type) tectonic movements, and the associated unstable pressure conditions. The consequence of the latter is heterogenization of the gas-water fluid, which, in turn, leads to the cavitation and froth flotation mechanisms.

Key words: spherical microparticles; gold-quartz veins; cavitation; flotation; metamorphism; minerals; genesis 
Recommended by E.V. Sklyarov

For citation: Tatarinov A.V., Yalovik L.I., Vanin V.A. 2016. Spherical microparticles from gold-bearing quartz veins of the Irokinda deposit, Western Transbaikalia. Geodynamics \& Tectonophysics 7 (4), 651662. doi:10.5800/GT-2016-7-4-0226.

Для цитирования: Татаринов А.В., Яловик Л.И., Ванин В.А. Сферические микрочастицы из золоторудных кварцевых жил Ирокиндинского месторождения (Западное Забайкалье) // Геодинамика и тектонофизика. 2016. T. 7. № 4. С. 651-662. doi:10.5800/GT-2016-7-4-0226.

\title{
СФЕРИЧЕСКИЕ МИКРОЧАСТИЦЫ ИЗ ЗОЛОТОРУДНЫХ КВАРЦЕВЫХ ЖИЛ ИРОКИНДИНСКОГО МЕСТОРОЖДЕНИЯ (ЗАПАДНОЕ ЗАБАЙКАЛЬЕ)
}

\author{
А. В. Татаринов¹, Л. И. Яловик ${ }^{1}$, В. А. Ванин ${ }^{2}$ \\ ${ }^{1}$ Геологический институт СО РАН, Улан-Удэ, Россия \\ ${ }^{2}$ Институт земной коры СО РАН, Иркутск, Россия
}

\begin{abstract}
Аннотация: Приведены результаты изучения вещественного состава рудных микрочастиц, извлеченных из золотосодержащих концентратов эксплуатируемой кварцевой жилы № 30 Ирокиндинского месторождения. Авторы попытались рассмотреть их происхождение в связи с опубликованными ранее результатами исследований структурно-геологических особенностей формирования рудного поля, а также тектонофизических условий образования многих золоторудных кварцевых жил, включая и жилу № 30, дополненных нашими наблюдениями.

Золоторудные кварцевые жилы локализованы в аллохтонной пластине (рис. 1), надвинутой на КеляноИрокиндинский пояс. Они выполняют зоны разломов северо-восточного простирания. Е.А. Намолов с помощью тектонофизического анализа системы «элементарная трещина - рудовмещающий шов (разрыв)» дал генетическое объяснение морфологии рудных кварцевых жил (включая жилу № 30) и условиям формирования вмещающих их зон разломов. Было установлено, что рудовмещающие разрывы представляют собой сочетания трещин скола и отрыва, возникающие при определенных положениях эллипсоида деформации в обстановке одностороннего горизонтального сжатия. Неоднократные внутриминерализационные подвижки обусловили полосчатые текстуры руд и многочисленные включения вмещающих пород в кварцевом матриксе жил.
\end{abstract}

Сферические частицы обладают зональным строением и состоят из металлических ядер и внешних сплошных или прерывистых оболочек, толщиной от 10 до 400 мкм (рис. 2, рис. 3). Ядра в основном сложены самородным Fe с примесью Fe, Mn, Al (таблица), содержания которых обычно не превышают 1.0-1.5 мас. \%.

Характерными особенностями минерального состава оболочек рассматриваемых сфероидных микрочастиц являются (таблица):

- широкое распространение графитовой матрицы, включающей минералы различных классов, кроме самородных;

- наличие пирита в группе рудных оксидов $\mathrm{Fe}, \mathrm{Mn}, \mathrm{Cr}, \mathrm{Ti}$;

- присутствие большой группы карбонатных минералов;

- наличие полевых шпатов и натросилита среди силикатов;

- присутствие минерала состава $\mathrm{CaBr}_{2}$;

- наличие мономинеральных кварцевых оторочек.

Следствием динамометаморфизма, т.е. деформационного или механохимического преобразования пород Ирокиндинского шарьяжа, а также автохтона (толща пород Келяно-Ирокиндинского пояса), является образование газоводной («гидротермальной») системы, способной к формированию рудных сферических частиц с низкотемпературными минеральными каемками.

Главная особенность строения сферических микрочастиц Ирокинды заключается в резком контрасте условий кристаллизации металлических ядер и их оторочек. Аналогичные условия, приводящие к образованию сходных по составу с рассматриваемыми сферулами контрастных минеральных ассоциаций, характеризуют газоводолитокластитовую и газоводную стадии формирования грязевых вулканов. Для этих стадий предложен кавитационный механизм образования металлических сферических частиц $\mathrm{Fe}, \mathrm{Fe}-\mathrm{Cr}$ и другого состава, сопровождающийся горением (пирогенный расплав) и пиролизом углеводородных компонентов флюида. Такой механизм, за исключением происхождения расплава (в нашем случае фрикционный), в наибольшей степени соответствует фактическим данным. Образование сфероидов осуществлялось, вероятно, в дорудную стадию формирования кварцевых жил.

Обнаруженные и изученные высокотемпературные металлические сферические микрочастицы можно рассматривать как своеобразные индикаторы условий функционирования рудообразующей системы динамометаморфического типа, продуцирующей золоторудную минерализацию на Ирокиндинском месторождении. По строению и вещественному составу они сильно отличаются от микросферул шлаков других забай- 
кальских золоторудных месторождений (Сухой Лог - черносланцевая и Первенец - малосульфидная золотокварцевая рудные формации), также принадлежащих к динамогенному генетическому типу. Однако рудообразующие системы сравниваемых месторождений объединяют два фактора, способствующие образованию сферических микрочастиц: высокая тектоническая активность, заключающаяся в неоднократном (импульсивном) проявлении тектонических подвижек, и иницируемые ею условия нестабильности режима давления. Следствием последнего является гетерогенизация газоводного флюида, в свою очередь обусловливающая появление механизмов кавитации и пенной флотации.

Ключевые слова: сферические микрочастицы; золотокварцевые жилы; кавитация; флотация; динамометаморфизм; минералы; генезис

\section{1. ВВЕДЕНИЕ}

Генезис сферических рудных и алюмосиликатных микрочастиц, которые известны в рудах многих золотокварцевых и золото-кварц-сульфидных месторождений, обычно связывают с явлением кавитации [Adushkin et al., 2006; Novgorodova et al., $2003,2004]$. При этом предполагается связь кавитационного механизма формирования этих образований с разрывной тектоникой, вызывающей гетерогенизацию рудоносных гидротермальных растворов и соответственно возникновение кавитационных пузырьков.

В последнее время аналогичные по строению и составу микросферулы установлены на месторождениях (Сухой Лог, Первенец) Ленского золоторудного района, рудные залежи которых возникли в результате динамометаморфических преобразований геохимически специализированных на благородные металлы рудовмещающих толщ [Tatarinov et al., 2014].

В предлагаемой статье приведены результаты изучения вещественного состава рудных микрочастиц, извлеченных из золотосодержащих концентратов эксплуатируемой кварцевой жилы № 30 Ирокиндинского месторождения. Авторы попытались рассмотреть их происхождение в связи с опубликованными ранее результатами исследований структурно-геологических особенностей формирования рудного поля, а также тектонофизических условий образования многих золоторудных кварцевых жил, включая и жилу № 30, дополненных нашими наблюдениями.

\section{2. ГЕОЛОГО-СТРУКТУРНЫЕ И ТЕКТОНОФИЗИЧЕСКИЕ ОСОБЕННОСТИ РУДНОГО ПОЛЯ ИРОКИНДИНСКОГО МЕСТОРОЖДЕНИЯ}

Рудное поле $\left(70 \mathrm{\kappa m}^{2}\right)$, наряду с известными месторождениями золота Юбилейное и Ирбинское, входит в состав Келяно-Ирокиндинской металлогенической (структурно-формационной) зоны, гра- ницы которой определяются, по одним представлениям, одноименным фрагментом Байкало-Муйского зеленокаменного пояса рифейского возраста [Mineeva, Arkhangelskaya, 2007; Tatarinov et al., 2014; Yalovik et al., 2011]. По другим данным, на новейших геодинамических схемах [Bulgatov, 2015] эта зона представлена рифейским рифтовым океаническим и островодужным террейном, трансформированным позднее в Средневитимскую складчатую дугу, и сформирована сдвигами СВ простирания, которыми обусловлена мозаично-блоковая структура металлогенической зоны. Для упомянутых месторождений установлена пространственно-генетическая связь золоторудной минерализации с динамометаморфическими комплексами, сформированными по базитам пикрит-коматиит-толеитовой серии [Tatarinov et al., 2014]. По геофизическим данным (электротомография) последних лет [Tat'kov et al., 2014], рассматриваемая зона характеризуется сложным блоковым строением, обусловленным развитием пологих шарьяжно-надвиговых и крутопадающих сдвиговых тектонических нарушений.

На геоэлектрических разрезах площади Ирокиндинского рудного поля [Tat'kov et al., 2014] сочетание пологопадающих и горизонтальных проводящих зон с крутопадающими образует структурный каркас, свойственный автокластическому (блоковому) меланжу. Золоторудные кварцевые жилы локализованы в аллохтонной пластине (рис. 1), надвинутой на Келяно-Ирокиндинский пояс. Будучи разбитой на блоки, она сложена, по одним сведениям, парагнейсами [Yatsenko, 1995], по другим кристаллическими сланцами и гнейсами, традиционно относимыми к раннедокембрийским образованиям Муйской глыбы [Konnikov et al., 1995]. Золотокварцевые жилы, иногда серповидной и г-образной формы, локализованы в линейных зонах тектонометаморфического преобразования вмещающих пород (катаклазиты, милониты, березитоподобные механометасоматиты), закартированные как зоны тектонического дробления и рассланцевания [Namolov, 1979a; Yatsenko, 1995]. Протяженность зон разломов от нескольких сотен метров 


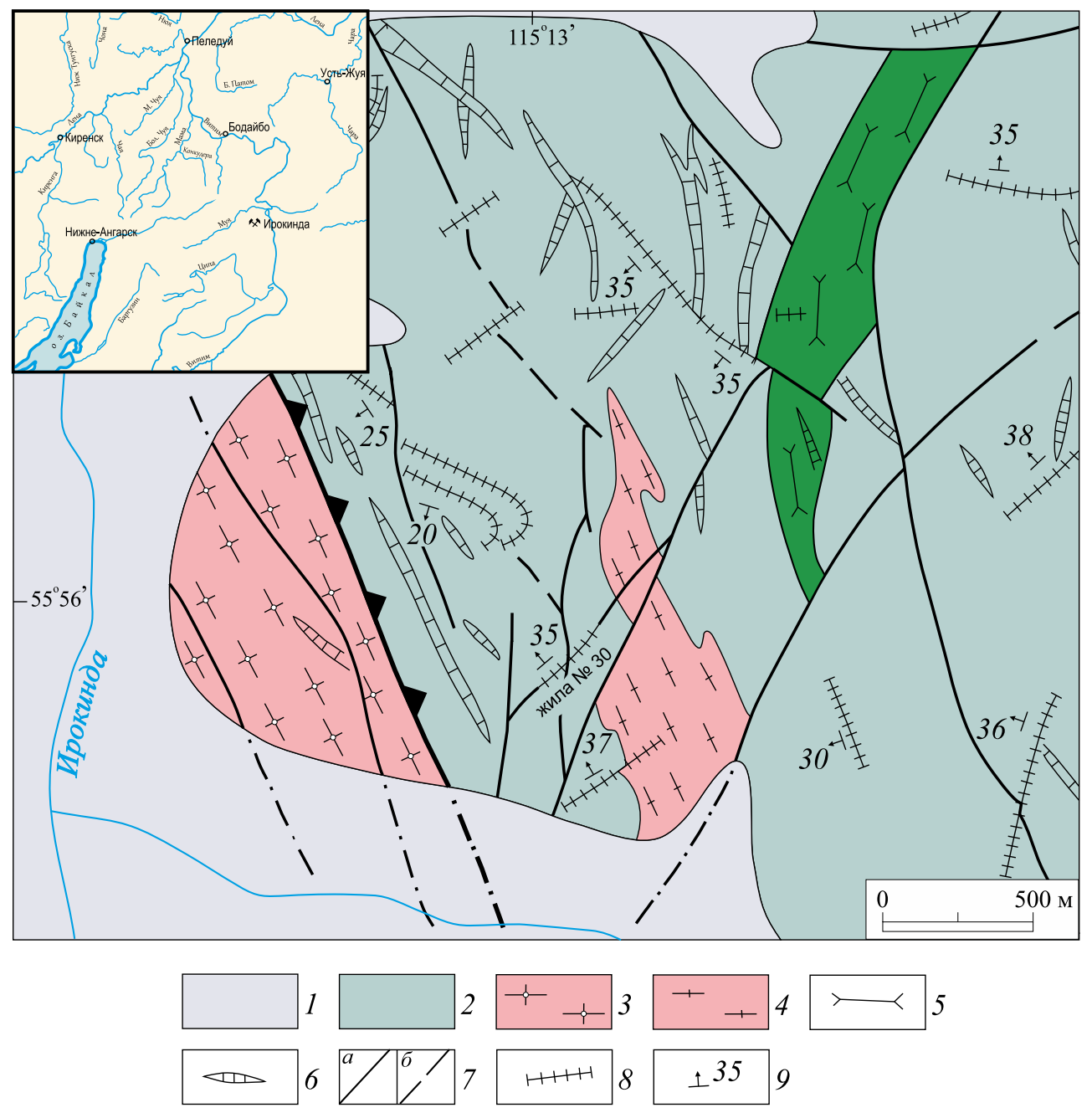

Рис. 1. Схема геологического строения месторождения участка с жилой № 30 Ирокиндинского золоторудного поля (по Е.А. Намолову [Namolov, 1987] с изменениями).

1 - четвертичные отложения; 2 - биотитовые, пироксен-биотитовые, гранат-биотитовые, гранатовые, амфибол-биотитовые гнейсы, амфиболовые, биотит-амфиболовые кристаллические сланцы, кристаллические известняки, кальцифиры; 3 - очковые гнейсограниты; 4 - аляскитовые и гнейсовидные граниты; 5 - ортоамфиболиты; 6 - дайки фельзитов, фельзит-порфиров, диоритов, диорит-порфиров; 7 - тектонические нарушения (а - установленные, б - предполагаемые); 8 - кварцевые жилы; 9 - элементы залегания золотокварцевых жил.

Fig. 1. Schematic geological structure of the deposit area with vein No. 30, the Irokinda gold field (from [Namolov, 1987], amended).

1 - Quaternary deposits; 2 - biotite, pyroxene-biotite, garnet-biotite, garnet, amphibole-biotite gneiss, amphibolite, biotite-amphibole crystalline schists, crystalline limestone, and calciphyres; 3 - spectacle gneiss granite; 4 - alyaskite and gneissic granites; 5 - ortoamphibolites; 6 - dikes of felsites, felsites-porphyres, diorite, and diorite porphyres; 7 - tectonic faults (a - confirmed, 6 - assumed); 8 - quartz veins; 9 - bedding elements of gold-quartz veins.

до первых километров, при мощности 1-10 м [Yatsenko, 1998]. Протяженность по простиранию кварцевых жил 400-600 м, по падению - 300-500 м. Мощность обычно варьируется от 0.4 до 2.5 м, достигая в раздувах 5-12 м. Наибольшей продуктивностью характеризуются жилы № 30 и Юрасовская размером $2.8 \times 0.3-0.6$ км. Они выполняют пологие зоны разломов северо-восточного простирания. E.A. Намолов [Namolov, 1979a] с помощью тектонофизического анализа системы «элементарная тре- щина - рудовмещающий шов (разрыв)» дал генетическое объяснение морфологии рудных кварцевых жил (включая жилу № 30) и условиям формирования вмещающих их разломов. При этом им использовались погоризонтные планы разведанных кварцевых жил, повторяющих изгибы рудовмещающих разрывов, а также массовые замеры элементов залегания последних. В результате было установлено, что рудовмещающие разрывы представляют собой сочетания трещин скола и отрыва, воз- 
никающие при определенных положениях эллипсоида деформации в обстановке одностороннего горизонтального сжатия. Также был показан дискретный характер единого поля напряжения и установлено, что с изменением ориентировки оси сжатия одни и те же элементарные трещины развивались то как сколы, то как трещины отрыва. По данным А.C. Яценко [Yatsenko, 1995], промышленные пологозалегающие кварцевые жилы приурочены к зонам разломов со сдвиговыми и малоамлитудными взбросовыми либо сбросовыми кинематическими перемещениями. Считается [Yatsenko, 1998], что неоднократные внутриминерализационные подвижки обусловили полосчатые текстуры руд и многочисленные включения вмещающих пород в кварцевом матриксе жил. Нами изучались отвалы нижней штольни, пройденной по жиле № 30. В их составе наряду с кварцем обнаружены обломки милонитизированных анортозитов и метагаббро, выходящих в подошве упомянутого выше шарьяжа. Кварц - двух разновидностей: в брекчии и жильный. Брекчии представлены зернистым кварцем, слагающим обломки. В цементе - его сливная разновидность. Обломки кварцевых брекчий пересечены трещинами, выполненными сульфидизированными (пирит, халькопирит) и ослюденелыми с примазками Аu включениями вмещающих пород. Жильный кварц обладает полосчатой текстурой (ранняя генерация), приобретенной за счет измененных включений вмещающих пород. Поздний сливной кварц их не содержит, ассоциирует с Fe-карбонатом. Содержания благородных металлов в пробе жильного кварца: $\mathrm{Au}=7.23$ г/т, $\mathrm{Ag}=2.02$ г/T, Pt=0.46 г/т.

В жиле № $30 \mathrm{Au}$ ассоциирует с пиритом, сфалеритом, галенитом и халькопиритом. Содержания сульфидов 1-2 \%. Из нерудных минералов в кварце этой жилы чаще всего встречаются карбонаты и серицит.

Возраст золоторудной минерализации Ирокиндинского месторождения по K-Ar датировкам серицита $-271 \pm 5$ млн лет, а по Rb-Sr - 275 7 млн лет, т.е. пермский, а не рифейский, как это предполагается [Kucherenko, 1989]. На основании изотопных данных по галенитам, ассоциирующим с золотом, Е.А. Намолов пришел к выводу, что источник рудного вещества - коровый [Namolov, 1979b]. Им являются породы рифейского возраста. С нашей точки зрения, это, в первую очередь, ультрабазит-базитовый комплекс Келяно-Ирокиндинского пояса.

\section{3. ВЕЩЕСТВЕННЫЙ СОСТАВ СФЕРИЧЕСКИХ ЧАСТИЦ}

Изученные рудные микрочастицы характеризуются шаровидной (диаметр 0.5-1.9 мм) и каплевид- ной (от $1.2 \times 1.3$ мм до $1.9 \times 2.0$ мм) формой (рис. 2, рис. 3). Они обладают зональным строением и состоят из металлических ядер и внешних сплошных или прерывистых оболочек, толщиной от 10 до 400 мкм.

Ядра в основном сложены самородным Fe с примесью $\mathrm{Fe}, \mathrm{Mn}, \mathrm{Al}$ (таблица), содержания которых обычно не превышают 1.0-1.5 мас. \%. Они содержат многочисленные округлые, пластинчатые, неправильные, а также близкие к кривогранным шестигранникам формы выделения размером от 1 до 300 мкм, очевидно выполняющие газовые пустоты. Кроме того, отмечаются нано- и микровключения, без видимой связи с газовыми порами, оксидов рудных минералов (нормативный состав) $\mathrm{Fe}, \mathrm{Mn}$, $\mathrm{Cr}$, Ti в парагенезисе с нерудными (силикаты, оксиды и сульфаты).

Ассоциация нано- и микроминералов газовых пустот, рассчитанных по стехиометрическим соотношениям элементов, также представлена оксидами тех же рудных элементов (таблица). Однако в срастании с ними более разнообразным является видовый состав нерудных минералов. Здесь появляется углеродистое вещество, вероятнее всего в форме графита, а также водные оксиды Al, фториды (жарчихит) и хлориды (сильвин).

Характерными особенностями минерального состава оболочек рассматриваемых сфероидных микрочастиц являются (таблица):

- широкое распространение графитовой матрицы, включающей минералы различных классов, кроме самородных;

- наличие пирита в группе рудных оксидов Fe, Mn, Cr, Ti;

- присутствие большой группы карбонатных минералов;

- наличие полевых шпатов и натросилита среди силикатов;

- присутствие минерала состава $\mathrm{CaBr}_{2}$;

- наличие мономинеральных кварцевых оторочек.

Анализ видового состава минералов, слагающих сфероидные микрочастицы, показывает, что по температурным условиям кристаллизации можно выделить три группы: 1) высокотемпературную $\left(\mathrm{T}>1000{ }^{\circ} \mathrm{C}\right)$, кристаллизующуюся из капель микрорасплава (самородное Fе и карбиды Fe, хромит, эсколаит, возможно ильменит, герцинит); 2) среднетемпературную (T=600-400 $\left.{ }^{\circ} \mathrm{C}\right)$, включающую полевые шпаты, корунд, магнетит, гематит, графит и другие минералы; 3) низкотемпературную $\left(\mathrm{T}<400{ }^{\circ} \mathrm{C}\right.$ ) (карбонаты, сульфаты, хлориды, некоторые силикаты). Минералы двух последних групп кристаллизовались в РТ-условиях, свойственных типичным гидротермальным образованиям. 


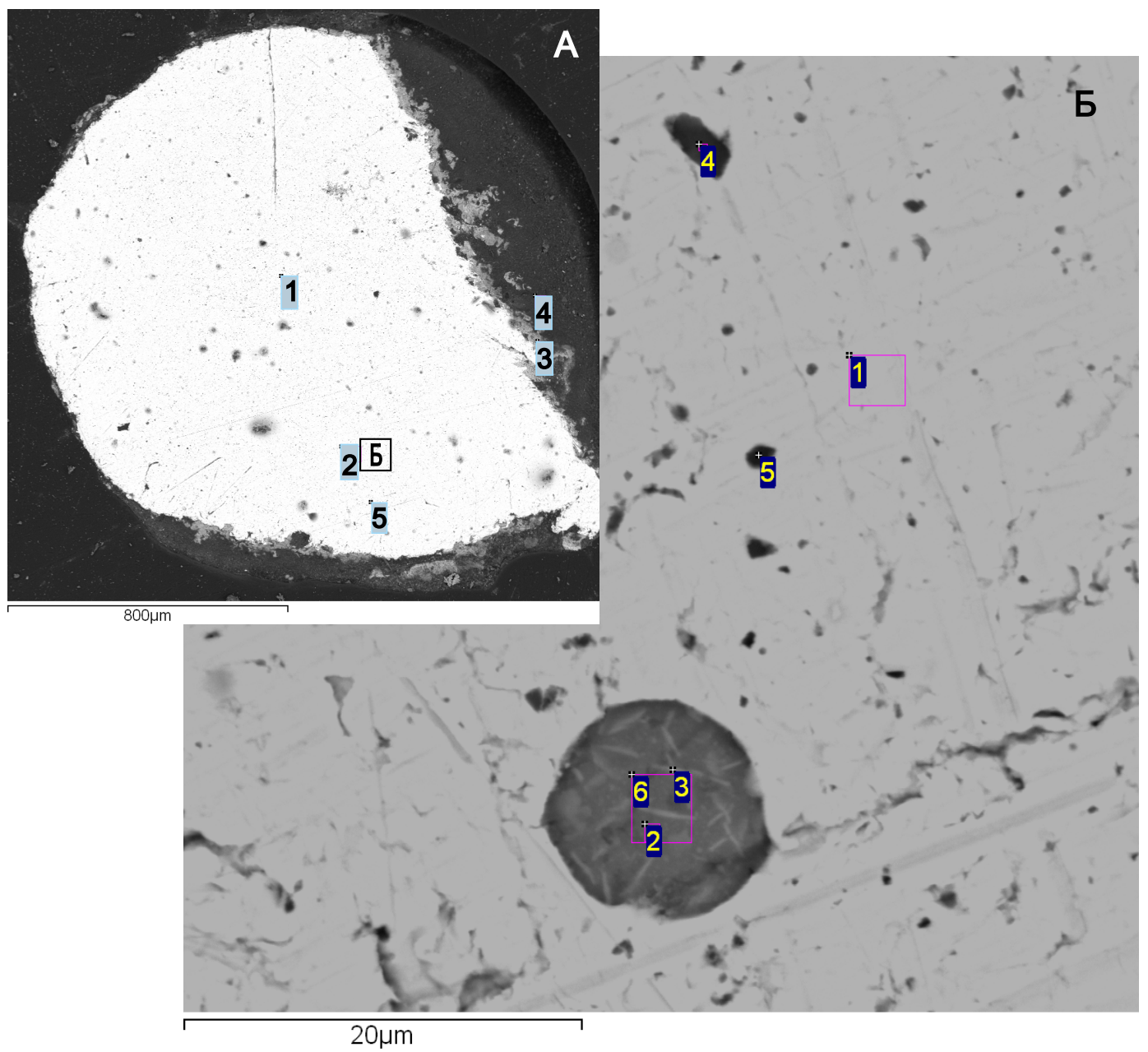

Рис. 2. Частица самородного железа микро- и нановключениями нормативных минералов, рассчитанных по стехиометрическим соотношениям химических элементов.

A: 1 - самородное железо с примесями (Fe - 96.39\%, C - 2.21\%, Cr - 0.68\%, Mn - 0.31\%); 2 - то же самое (Fe - $95.23 \%, \mathrm{C}-3.8 \%$, $\mathrm{Cr}-0.57 \%$, Mn - 0.4 \%); включение в самородном железе, представленное ассоциацией: кварц - $30.1 \%$, манганозит - $24.1 \%$, Мnильменит - $17.9 \%$, гиббсит - $13.5 \%$, графит - $4.8 \%$, ильменит - $4.1 \%$, хромит - $3.0 \%$, сомольноскит - $2.5 \%$. Минералы в оболочке частицы, анализы 3 и 4: 3 - гематит - $53.08 \%$, герцинит - 7.3\%, гипс - $2.9 \%$, нахколит - $2.5 \%$, сомольноскит - $2.1 \%$, хромит - $1.4 \%$, сильвин - $0.6 \%$, ильменит - $0.5 \%$, манганозит - $0.3 \%$; 4 - кальцит $-13.9 \%$, кварц - $1.4 \%$, гиббсит - $0.8 \%$, гипс $0.7 \%$, лавренсит - $0.4 \%$, сильвин - $0.4 \%: 5$ - включение в самородном железе, представленное ассоциацией: кварц - $30.1 \%$, манганозит - $24.1 \%$, Мn-ильменит - $17.9 \%$, гиббсит - $13.5 \%$, графит - $4.8 \%$, ильменит - $4.1 \%$, хромит - $3.0 \%$, сомольноскит $2.5 \%$. Б: включение в виде кривогранного шестигранника (точки анализов $2,3,6)$ и более мелкие включения $(4,5)$ в частице самородного железа (1), имеющего состав в (\%): $\mathrm{Fe}-96.86, \mathrm{C}-2.32, \mathrm{Cr}-0.52, \mathrm{Mn}-0.29$. Минералы «шестигранника»: 2 - кварц $34.7 \%$, манганозит - $28.6 \%$, гиббсит - $16.1 \%$, графит - $9.1 \%$, ильменит - $6.5 \%$, эсколаит - $2.9 \%$, сомольносит - $2.5 \%$; 3 Мn-ильменит - $24.5 \%$, кварц - $23.9 \%$, манганозит - $20.3 \%$, ильменит - 7 \%, гиббсит - $10.6 \%$, самольеноскит - $1.8 \%$, эсколаит $1.5 \%$; 4 - герцинит - $72.8 \%$, корунд - $27.2 \%$; 5 - герцинит - $43.2 \%$, графит - $35.3 \%$, корунд - 20.5 \%, ильменит - $1 \%, 6$ - манганозит - $27.2 \%$, Мn-ильменит - $10.0 \%$, жарчихит - $7.7 \%$, гиббсит - $7.1 \%$, ильменит - $6 \%$, графит - $4.4 \%$, эсколаит - $2.8 \%$, сомольноскит $-2.6 \%$.

Fig. 2. The particle of native iron with micro- and nano-inclusions of normative minerals, calculated from stoichiometric ratios of chemical elements.

$A$ : 1 - native iron with admixtures (Fe - 96.39\%, C - 2.21\%, $\mathrm{Cr}-0.68 \%, \mathrm{Mn}-0.31 \%) ; 2-$ same (Fe $-95.23 \%, \mathrm{C}-3.8 \%, \mathrm{Cr}-0.57 \%, \mathrm{Mn}$ $-0.4 \%$ ); 5 - inclusion in native iron, represented by the association: quartz $-30.1 \%$, manganozite $-24.1 \%$, Mn-ilmenite $-17.9 \%$, gibbsite $-13.5 \%$, graphite $-4.8 \%$, ilmenite $-4.1 \%$, chromite $-3.0 \%$, somolnoskite $-2.5 \%$. Minerals in the shell of the particles (analyses 3 and 4): hematite $-53.08 \%$ hercynite $-7.3 \%$ gypsum $-2.9 \%$, nahcolite $-2.5 \%$ somolnoskite $-2.1 \%$, chromite $-1.4 \%$ sylvine $-0.6 \%$, ilmenite $-0.5 \%$ manganozit $-0.3 \%$; $4--13.9 \%$ calcite, quartz $-1.4 \%$, gibbsite $-0.8 \%$, gypsum $-0.7 \%$, lavrensite $-0.4 \%$, sylvine -0.4 $\%$. 5 : inclusion shaped as an irregular hexagon (analysis points 2, 3, and 6) and finer inclusions (4, and 5) in the particle of native iron (1), which composition (\%) is as follows: $\mathrm{Fe}-96.86, \mathrm{C}-2.32, \mathrm{Cr}-0.52, \mathrm{Mn}-0.29$. Minerals in the 'hexagon': $2-$ quartz - 34.7 \%, manganozite $-28.6 \%$, gibbsite $-16.1 \%$, graphite $-9.1 \%$, ilmenite - $6.5 \%$, eskolaite $-2.9 \%$, somolnosite - $2.5 \%$; 3 - Mn-ilmenite - $24.5 \%$, quartz $23.9 \%$, manganozite $-20.3 \%$, ilmenite $-7.0 \%$, gibbsite $-10.6 \%$, samolenoskite $-1.8 \%$, eskolaite $-1.5 \%$; $6-$ manganozite $-27.2 \%$, Mn-ilmenite - $10.0 \%$, zharchihite $-7.7 \%$, gibbsite $-7.1 \%$, ilmenite $-6.0 \%$, graphite $-4.4 \%$, eskolaite $-2.8 \%$, somolnoskite - $2.6 \%$. Other micro-inclusions: 4 - hercynite $-72.8 \%$, corundum - $27.2 \%$; 5 - hercynite $-43.2 \%$, graphite $-35.3 \%$, corundum - $20.5 \%$ ilmenite $-1.0 \%$. 


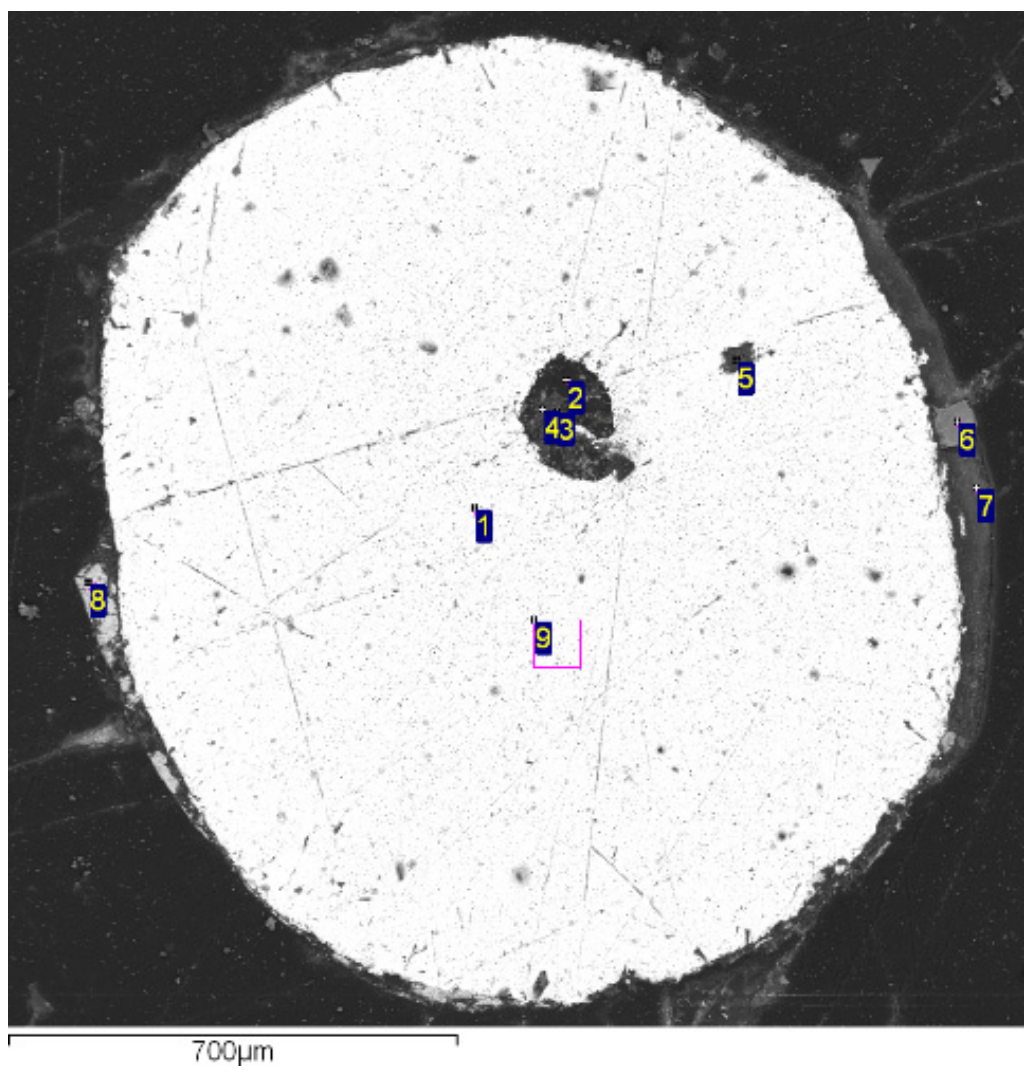

Рис. 3. Сферическая частица карбида железа с включениями нормативных минералов.

1, 9 - карбид железа (1 - Fe - 87.4 мас. \%, C - 9.39 \%; 9 - Fe - 85.2 \%, C - 14.05 \%, Al - 0.75 \%). Включения: 2 - графит с примесью $0-4.17 \%, \mathrm{Cl}-0.5 \%$; 3 - кальцит - $67.8 \%$, графит - $31.1 \%$, кварц - $1.2 \%$, гиббсит - $0.9 \%$; 4 - графит - 76.7 \%, кальцит - $11.6 \%$, эпсомит $-3.4 \%$, нахколит - $3.3 \%$, альбит $-2.7 \%$, гиббсит - $0.6 \%$, пирит - $0.6 \%$, галит - $0.5 \%$, сильвин - $0.3 \%$, тенардит - $0.3 \%$; 5 - графит - $60.8 \%$, кальцит - $29.3 \%$, эпсомит - $4.3 \%$, альбит - $3.1 \%$, гипс - $1.4 \%$, кварц - $0.4 \%$, сильвин - $0.4 \%$, галит - $0.2 \%$, нахколит - $0.1 \%$. Оторочка сферической частицы: 6 - кварц - $39.1 \%$, натросилит - 24.0\%, альбит - 10.8 \%, магнезит - $9.1 \%$, кальцит - $8.6 \%$, калицинит - 2.0; 7 - кальцит - $11.1 \%$, графит - 8.1\%, кварц - $2.1 \%$, магнезит - $1.7 \%$, нахколит - $1.7 \%$, СаВr 2 $1.3 \%$, сильвин - $0.6 \%$, сидерит - $0.4 \%$, галит - $0.3 \%$, пирит - $0.3 \%$; 8 - магнетит - $51.3 \%$, якобсит - $22.7 \%$, ильменит - $7.8 \%$, графит $-7.6 \%$, кварц $-6.8 \%$, кальцит $-1.9 \%$, корунд $-1.5 \%$, хромит $-0.4 \%$.

Fig. 3. The spherical particle of iron carbide with inclusions of normative minerals.

1, 9 - iron carbide ( 1 - Fe - 87.4 wt \%, C - 9.39\%; 9 - Fe - $85.2 \%, \mathrm{C}-14.05 \% \mathrm{Al}-0.75 \%$ ). Inclusions: 2 - graphite with admixtures of 0 $-4.17 \%$, Cl $-0.5 \%$; 3 - calcite $-67.8 \%$, graphite $-31.1 \%$, quartz $-1.2 \%$, gibbsite $-0.9 \%$; 4 - graphite $-76.7 \%$, calcite - $11.6 \%$, epsomite $-3.4 \%$, nahcolite $-3.3 \%$, albite $-2.7 \%$, gibbsite $-0.6 \%$, pyrite $-0.6 \%$, halite $-0.5 \%$, sylvine $-0.3 \%$, thenardite $-0.3 \%$; 5 - graphite $-60.8 \%$, calcite $-29.3 \%$, epsomite $-4.3 \%$, albite $-3.1 \%$, gypsum $-1.4 \%$, quartz $-0.4 \%$, sylvine $-0.4 \%$, halite $-0.2 \%$, nahcolite $-0.1 \%$. The rim of the spherical particle: 6 - quartz $-39.1 \%$, natrosilite $-24.0 \%$, albite $-10.8 \%$, magnesite $-9.1 \%$, calcite $8.6 \%$, kalicinite $-2.0 ; 7$ - calcite $-11.1 \%$, graphite $-8.1 \%$, quartz $-2.1 \%$, magnesite $-1.7 \%$, nahcolite $-1.7 \%$, CaBr2 $-1.3 \%$, sylvine $0.6 \%$, siderite $-0.4 \%$, halite $-0.3 \%$, pyrite $-0.3 \%$; 8 - magnetite $-51.3 \%$, jacobsite $-22.7 \%$, ilmenite $-7.8 \%$, graphite $-7.6 \%$, quartz $-6.8 \%$, calcite $-1.9 \%$, corundum $-1.5 \%$, chromite $-0.4 \%$.

\section{4. ГЕНЕЗИС СФЕРОИДНЫХ РУДНЫХ МИКРОЧАСТИЦ}

Металлические, шлаковые и алюмосиликатные микросферулы известны во многих золоторудных месторождениях гидротермального генезиса. Так, в рудах золотокварцевых и золото-кварц-сульфидных месторождений Якутии, Узбекистана и Аляски широко распространены сферические микрочастицы алюмосиликатных стекол [Novgorodova et al., 2003]. В золотокварцевых жилах месторождения Келлям (Якутия) установлены рудные микросфе- рулы двух типов [Novgorodova et al., 2004]: мономинеральные (Au, галенит, антимонит, пирротин) и зональные полиминеральные с «золотым» ядром и галенит-буланжеритовой каймой. Температурный диапазон их кристаллизации $>850-200{ }^{\circ} \mathrm{C}$.

В золотоносных кварцевых жилах Ленского района динамометаморфического происхождения выявлены также сферические частицы микрошлаков. В жильных рудах золотокварцевого месторождения Первенец установлены их зональные сферулы, состоящие из ядер самородного $\mathrm{Fe}$ и оболочек, 
A.V. Tatarinov et al.: Spherical microparticles from gold-bearing quartz veins...

\section{Минеральный состав металлических сфероидных микрочастиц из золотокварцевой жилы № 30 Ирокиндинского месторождения}

The mineral composition of metal spheroidal microparticles from gold-quartz vein No. 30, Irokinda deposit

\begin{tabular}{|c|c|c|}
\hline Элементы структуры частиц & Рудные минералы & Минералы в ассоциации с рудными \\
\hline Металлические ядра & $\begin{array}{l}\text { Самородное Fe с примесью } \mathrm{Cr}, \mathrm{Mn} \text { и } \mathrm{Al}, \\
\text { карбиды Fe с примесью Mn (когенит и } \\
\left.\mathrm{Fe}_{2} \mathrm{C}\right), \text { магнетит, гематит, ильменит, } \\
\text { Mn-ильменит, манганозит, хромит, } \\
\text { герцинит }\end{array}$ & $\begin{array}{l}\text { Кварц, гиббсит, сомольноскит, корунд, } \\
\text { роценит, илезит }\end{array}$ \\
\hline $\begin{array}{l}\text { Газовые пустоты (каверны) в } \\
\text { металлических ядрах, выполнен- } \\
\text { ные минеральным веществом }\end{array}$ & $\begin{array}{l}\text { Манганозит, Mn-ильменит, ильменит, } \\
\text { хромит, эсколаит, герцинит, гётит }\end{array}$ & $\begin{array}{l}\text { Графит, кварц, мусковит, корунд, гиббсит, } \\
\text { диаспор, термонатрит, сильвин, жарчихит, } \\
\text { гипс, сомольноскит }\end{array}$ \\
\hline Оторочки металлических ядер & $\begin{array}{l}\text { Магнетит, гематит, гётит, манганозит, } \\
\text { хромит, ильменит, якобсит, пирит }\end{array}$ & $\begin{array}{l}\text { Графит, кварц, калишпат, альбит, натросилит, } \\
\text { корунд, гиббсит, магнезит, трона, калицинит, } \\
\text { нахколит, сильвин, СaBr2, сомольноскит, гипс, } \\
\text { лавренсит, тенардит }\end{array}$ \\
\hline
\end{tabular}

сложенных в различной степени раскристаллизованными шлаковыми стеклами [Tatarinov, Yalovik, 2014]. В нормативном составе подверженной раскристаллизации стеклофазы основная роль принадлежит иоциту, ильмениту, фаялиту и ларниту. Наиболее распространенной является точка зрения на кавитационный механизм образования сферических микрочастиц в золоторудных кварцевых жилах, обусловленный гетерогенизацией гидротермальных флюидов [Novgorodova et al., 2003, 2004]. На примерах Ленского золотоносного района и литокомплексов грязевых вулканов юга Восточной Сибири обосновывается (допускается) существование, кроме кавитационного, флотационного и микроликвационного механизмов [Tatarinov, Yalovik, 2014; Tatarinov et al., 2016], являющихся следствием динамометаморфических (механохимических) процессов.

Для зональных рудных сферул жилы № 30 Ирокиндинского месторождения рассмотрим возможности реализации каждого из перечисленных выше генетических механизмов.

\section{1. КАВИТАЦИОННЫЙ МЕХАНИЗМ}

Необходимым условием для реализации данного механизма является гетерогенизация (вскипание) газоводного флюида. Гетерогенизация последнего в ходе формирования золоторудных кварцевых жил Ирокиндинского месторождения, прежде всего, определяется неоднократным проявлением тектонических процессов как в дорудной, так и в рудной стадии. Флюид при тектонических подвижках гетерогенизировался на две фазы: жидкую водно-углекислотно-сульфатно-хлоридную, из которой сформировалась оторочка сфероидов, и газовую (угле- водороды, CO). Последняя инициировала кавитационные явления, сопровождающиеся кристаллизацией высокотемпературной ассоциации минералов ядер сфероидов (самородное $\mathrm{Fe}$, карбиды $\mathrm{Fe}$, оксиды). Ранее проведенные термобарогеохимические исследования газово-жидких включений в рудных кварцах жил Юрасовской и Тулуинской Ирокиндинского месторождения [Lyakhov, 1980] показали значительную роль гетерогенных углекислотно-водных растворов в формировании продуктивной стадии рудогенеза. Таким образом, участие кавитационного механизма в образовании рассматриваемых рудных частиц вполне возможно.

\section{2. ФЛОТАЦИОННЫЙ И ЛИКВАЦИОННЫЙ МЕХАНИЗМЫ}

Эти одновременно действующие механизмы хорошо изучены в экспериментах по плавлению и кристаллизации смесей силикатных горных пород с известняками [Ovchinnikov, 1988]. Они характеризуют поведение рудного вещества, отделившегося от магматического расплава. Согласно опытам, сначала происходит образование отдельных мелких рассеянных капель вследствие ликвации, затем их концентрирование в виде каймы вокруг газовых пузырей с последующим проникновением еe внутрь пузырей. Внутри пузырей рудное вещество преобразуется (коалесценция) в форму укрупненной капли и этим пузырем выносится наверх, затвердевая в виде микросферул. По такой схеме, аналогичной процессу пенной флотации [Ovchinnikov, 1988], в упомянутых экспериментах были получены шарики Fe без оторочек, достигающие 2 мм в диаметре. Н.С. Остапенко на примерах многих золоторудных месторождений кварцево-жильного типа, включая Ирокиндинское, обосновал форми- 
рование богатых рудных столбов по механизму газовой флотации гидрофобных минералов (самородное $\mathrm{Au}$, сульфиды) в рудообразующем флюиде [Ostapenko, 2016].

Ликвационное происхождение при участии восстановленных флюидов предполагается для пористых зональных силикатно-металлических сферул (микрошлаков) из кислых вулканитов Приморья [Grebennikov et al., 2012], ядра которых сложены самородным Fe с примесью графита и карбидами $\mathrm{Fe}$ (до когенита), а оторочки - симплектитовыми агрегатами кварца, стекла и магнетита. По составу и строению эти микрошлаки близки таковым из золоторудных динамосланцев Сухого Лога и кварцевых жил месторождения Первенец Ленского района.

Из приведенных данных следует, что механизмы флотации и ликвации нельзя исключить из модели образования рудных сфероидных частиц в кварцевых жилах Ирокиндинского месторождения.

\section{5. ОСОБЕННОСТИ ДИНАМОМЕТАМОРФИЧЕСКОЙ МОДЕЛИ ФОРМИРОВАНИЯ РУДНЫХ СФЕРОИДНЫХ ЧАСТИЦ ИРОКИНДИНСКОГО МЕСТОРОЖДЕНИЯ}

По аналогии с месторождениями Ирбинским, Сухоложским, Первенец [Tatarinov, Yalovik, 2014; Tatarinov et al., 2014] авторами предполагается динамометаморфическое происхождение и для золоторудных кварцевых жил, березитоподобных образований Ирокиндинского поля. Следствием динамометаморфизма, т.е. деформационного или механохимического преобразования пород Ирокиндинского шарьяжа, а также автохтона (толща пород Келяно-Ирокиндинского пояса), является образование газоводной («гидротермальной») системы, способной к формированию рудных сферических частиц с низкотемпературными минеральными каемками. Как показывают эксперименты [Chersky, Tsarev, 1984], при динамометаморфизме практически любых петротипов горных пород могут возникнуть $\mathrm{H}_{2}, \mathrm{~N}_{2}, \mathrm{CO}_{2}, \mathrm{O}_{2}, \mathrm{CH}_{4}$, тяжелые углеводороды в различных количественных соотношениях. При наличии органического вещества в осадочных горных породах (в нашем случае мухтунная свита [Kucherenko et al., 1990]) в условиях тектонических воздействий также происходит его механохимическое преобразование с генерацией компонентов нефтяного ряда [Chersky, Soroko, 1988]. Общеизвестно образование водного компонента в процессе динамометаморфизма: извлечение поровых вод из ассоциаций безводных минералов, затем формирование водных силикатов, оксидов, карбонатов и сульфатов. Деформационное разложение минералов, содержащих в своем соста- ве ОН-группировки, в свою очередь приводит к обособлению гидротермального раствора. Параллельно осуществляется мобилизация $\mathrm{Cl}, \mathrm{F}, \mathrm{Br}$ с последующим связыванием их в минеральных формах.

Главная особенность строения сферических микрочастиц Ирокинды заключается в резком контрасте условий кристаллизации металлических ядер (высокотемпературный расплав) и их оторочек (средне- и низкотемпературный водный флюид). Аналогичные условия, приводящие к образованию сходных по составу с рассматриваемыми сферулами контрастных минеральных ассоциаций, характеризуют газоводолитокластитовую и газоводную стадии формирования грязевых вулканов [Tatarinov et al., 2016]. Для этих стадий предложен кавитационный механизм образования металлических сферических частиц $\mathrm{Fe}, \mathrm{Fe}-\mathrm{Cr}$ и другого состава, сопровождающийся горением (пирогенный расплав) и пиролизом углеводородных компонентов флюида. Такой механизм, по мнению авторов данной статьи, в наибольшей степени соответствует фактическим данным. Только расплав был не пирогенным, а фрикционным. Образование сфероидов осуществлялось, вероятно, в дорудную стадию формирования кварцевых жил.

\section{6. ЗАКЛЮЧЕНИЕ}

Обнаруженные и изученные авторами высокотемпературные металлические сферические микрочастицы, заключенные в оболочки средне- и низкотемпературных минералов, можно рассматривать как своеобразные индикаторы условий функционирования рудообразующей системы динамометаморфического типа, продуцирующей золоторудную минерализацию на Ирокиндинском месторождении. По строению и вещественному составу они сильно отличаются: 1) от микросферул шлаков других забайкальских золоторудных месторождений (Сухой Лог - черносланцевая и Первенец - малосульфидная золотокварцевая рудные формации), также принадлежащих к динамогенному генетическому типу; 2) от сферических микрочастиц, выявленных в рудных жилах золотокварцевых и золото-кварц-сульфидных месторождений других регионов [Novgorodova et al., 2003, 2004], относимых к типичным гидротермальным образованиям. Однако рудообразующие системы сравниваемых золоторудных месторождений объединяют два фактора, способствующие образованию сферических микрочастиц: высокая тектоническая активность, заключающаяся в неоднократном (импульсивном) проявлении тектонических подвижек, и иницируемые ею условия нестабиль- 
ности режима давления. Следствием последнего является гетерогенизация газоводного флюида, в свою очередь, обусловливающая появление механизмов кавитации и пенной флотации, благодаря которым и формируются рассматриваемые сферические образования.

\section{7. БЛАГОДАРНОСТИ}

Работа выполнена при поддержке РФФИ (проекты № 16-35-60033, 16-35-00042) и РНФ (проект № 16-17-10180) в части изучения вещественного состава руд.

\section{8. ЛИТЕРАTУРА / REFERENCES}

Adushkin V.V., Andreev S.N., Popel S.I., 2006. Formation of nano-and microspherules of minerals in ore deposits depending on depth of host rock occurrence. Geology of Ore Deposits 48 (3), 237-243. http://dx.doi.org/10.1134/ S1075701506030056.

Bulgatov A.N., 2015. Geodynamics of the Baikal mountainous region in the Late Riphean and Vendian - Early Paleozoic. Geo, Novosibirsk, 191 p. (in Russian) [Булгатов А.Н. Геодинамика Байкальской горной области в позднем рифее и венде - раннем палеозое. Новосибирск: “Гео”, 2015. 191 с.].

Chersky N.V., Soroko T.I., 1988. The influence of tectonoseismic processes of the fossil organic matter and oil generation. Geologiya i Geofizika (Russian Geology and Geophysics) (9), 54-62(in Russian) [Черский Н.В., Сороко Т.И. Влияние тектоносейсмических процессов на ископаемое органическое вещество и генерацию нефти // Геология и геофизика. 1988. № 9. С. 54-62].

Chersky N.V., Tsarev B.P., 1984. The mechanism of the synthesis of hydrocarbons from inorganic compounds in the upper layers of the crust. Doklady AN SSSR 279 (3), 730-735(in Russian) [Черский Н.В., Царев Б.П. Механизм синтеза углеводородов из неорганических соединений в верхних горизонтах земной коры // Доклады $A H$ CCCP. 1984. Т. 279. № 3. С. 730-735].

Grebennikov A.V., Shcheka S.A., Karabtsov A.A., 2012. Silicate-metallic spherules and the problem of the ignimbrite eruption mechanism: The Yakutinskaya volcanic depression. Journal of Volcanology and Seismology 6 (4), 211-229. http://dx.doi.org/10.1134/S0742046312040021.

Konnikov E.G., Mironov A.G., Tsygankov A.A., Posokhov V.F., Vrublevskaya T.T., Kulikov A.A., Kulikova A.B., 1995. Genesis of plutonogenic gold mineralization in the Late Precambrian, Sayan-Baikal folded area. Geologiya $i$ Geofizika (Russian Geology and Geophysics) 36 (4), 37-52 (in Russian) [Конников Э.Г., Миронов А.Г., Цыганков А.А., Посохов В.Ф., Врублевская Т.Т., Куликов А.А., Куликова А.Б. Генезис плутоногенного золотого оруденения в позднем докембрии Саяно-Байкальской складчатой области // Геология и геофизика. 1995. Т. 36. № 4. С. 37-52].

Kucherenko I.V., 1989. The Late Paleozoic era of gold mineralization in the Precambrian frame of the Siberian platform. Izvestiya AN SSSR, Seriya Geologicheskaya (6), 90-101 (in Russian) [Кучеренко И.В. Позднепалеозойская эпоха золотого оруденения в докембрийском обрамлении Сибирской платформы // Известия $A H$ CCCP, серия геологическая. 1989. № 6. С. 90-101].

Kucherenko I.V., Larskaya E.S., Pankina R.G., Sukhova A.N., Chetverikova O.P., Pentina T.Yu., Korolev Yu.M., 1990. Distribution and sources of carbon in the near-ore metasomatic halos of terrigenous shale strata in the Baikal-Vitim geosynclinals-folded system. Geokhimiya (Geochemistry) (6), 797-806 (in Russian) [Кучеренко И.В., Ларская E.C., Панкина Р.Г., Сухова А.Н., Четверикова О.П., Пентина Т.Ю., Королев Ю.М. Распределение и источники углерода в околорудных метасоматических ореолах терригенно-сланцевых толщ Байкало-Витимской геосинклинально-складчатой системы // Геохимия. 1990. № 6. С. 797-806].

Lyakhov Yu.V., 1980. Paleotemperature zoning of ore fields. In: V.G. Moiseenko (Ed.), Thermobarogeochemistry and ore genesis. Proceedings of the 6th All-Union Conference on Thermobarogeochemistry. Far Eastern Scientific Center of the USSR Academy of Sciences, Vladivostok, P. 20-30 (in Russian) [Ляхов Ю.В. Палеотемпературная зональность рудных полей // Термобарогеохимия и рудогенез: Материалы VI Всесоюзного совещания по термобарогеохимии / Ред. В.Г. Моисеенко. Владивосток: ДВНЦ АН СССР, 1980. С. 20-30].

Mineeva I.G., Arkhangelskaya V.V., 2007. A new trend in the methodology of the discovery of uranium and golduranium deposits in shields and the Precambrian folded regions. Razvedka i okhrana nedr (Exploration and Conservation of Mineral Resources) (11), 18-25 (in Russian) [Минеева И.Г., Архангельская В.В. Новое направление в методологии выявления урановых и золотоурановых месторождений на щитах и в докембрийских складчатых областях // Разведка и охрана недр. 2007. № 11. С. 18-25].

Namolov E.A., 1979a. Tectonic conditions of formation and regularities of ore-bearing fractures in the Irokinda ore field. In: Ts.O. Ochirov (Ed.), Tectonic structures and regularities of minerals distribution in the territory of Transbaikalia. Publishing House of the Buryatian Branch, SB of the USSR Acad. Sci., Ulan-Ude, p. 70-79 (in Russian) [Намолов E.A. Тектонические условия формирования и закономерности морфологии рудовмещающих разрывов Ирокиндинского рудного поля // Тектонические структуры и закономерности размещения полезных ископаемых на территории Забайкалья / Ред. Ц.О Очиров. Улан-Удэ: Изд-во Бурятского филиала СО АН СССР, 1979. С. 70-79].

Namolov E.A., 1979b. The Evolution of the Structure and Endogenous Zoning of Mineralization in the Irokinda Gold Field. Thesis (Candidate of Geology and Mineralogy). Irkutsk, 150 p. (in Russian) [Намолов Е.А. Эволюция струк- 
туры и эндогенная зональность минерализации Ирокиндинского золоторудного поля: Дис. ... канд. геол.мин. наук. Иркутск, 1979. 150 с.].

Namolov E.A., 1987. Structural, mineralogical and geochemical criteria for evaluating gold-quartz veins (the case of an ore field in Buryatia). In: Gold mineralization south of Eastern Siberia. SNIIGGiMS, Novosibirsk-Irkutsk, p. 71-80 (in Russian) [Намолов Е.A. Структурные и минералого-геохимические критерии оценки золотокварцевых жил (на примере одного из рудных полей Бурятии) // Золотоносность юга Восточной Сибири. Новосибирск-Иркутск: СНИИГГиМС, 1987. С. 71-80].

Novgorodova M.I., Gamyanin G.N., Zhdanov Y.Y., Agakhanov A.A., Dikaya T.V., 2003. Microspherules of aluminosilicate glass in gold ores. Geochemistry International 41 (1), 76-85.

Novgorodova M.I., Gamyanin G.N., Zhdanov Y.Y., Agakhanov A.A., Dikaya T.V., 2004. Microspherules of native gold, sulfides, and sulfosalts in gold ores. Geochemistry International 42 (2), 122-133.

Ostapenko N.S., 2016. About the natural flotation of hydrophobic minerals in the hydrothermal mineralization and its consequences (cases of gold deposits). Rudy i Metally (Ores and Metals) (1), 78-86 (in Russian) [Остапенко Н.C. 0 естественной флотации гидрофобных минералов в гидротермальном рудообразовании и ее следствиях (на примере месторождений золота) // Руды и металлы. 2016. № 1. С. 78-86].

Ovchinnikov L.N., 1988. The Formation of Ore Deposits. Nedra, Moscow, 255 p. (in Russian) [Овчинников Л.Н. Образование рудных месторождений. М.: Недра, 1988. 255 с.].

Tatarinov A.V., Yalovik L.I., 2014. Placer-forming Cenozoic mud-volcano genetic type of gold mineralization in the Lena Area, Patom Highland, Russia. Global Journal of Earth Science and Engineering 1 (1), 24-33. http://dx.doi. org/10.15377/2409-5710.2014.01.01.3.

Tatarinov A.V., Yalovik L.I., Kanakin S.V., 2016. The generation and mineral associations of rock assemblages at mud volcanoes: Southeastern Siberia. Journal of Volcanology and Seismology 10 (4), 248-262. http://dx.doi.org/ 10.1134/S0742046316030052.

Tatarinov A.V., Yalovik L.I., Posokhov V.F., 2014. Features of formation of the Irba deposit of precious metals (Western Transbaikalia). Geology and Mineral Resources of Siberia 3 (1), 117-119 (in Russian) [Татаринов А.В., Яловик Л.И., Посохов В.Ф. Особенности формирования Ирбинского месторождения благородных металлов (Западное Забайкалье) // Геология и минерально-сырьевые ресурсы Сибири. 2014. № 3. Ч. 1. С. 117-119].

Tat'kov I.G., Tat'kov G.I., Baderin I.M., Kovbasov K.V., 2014. Electric tomography results in the search for gold ore in conditions of cryolatogenesis and the Alpine-type relief of Northern Pribaikalie. Razvedka i okhrana nedr (Exploration and Conservation of Mineral Resources) (1), 32-38 (in Russian) [Татьков И.Г., Татьков Г.И., Бадерин И.М., Ковбасов К.В. Результаты электротомографии при поисках рудного золота в условиях криолатогенеза и альпинотипного рельефа Северного Прибайкалья // Разведка и охрана недр. 2014. № 1. С. 32-38].

Yalovik L.I., Shelkovnikova N.A., Tatarinov A.V., 2011. Complex ores of the Jubilee ore field (Muya gold ore region). In: E.V. Kislov (Ed.), Minerageny of the Northeast Asia. Materials of the 2nd All-Russia scientific-practical conference. Ekos, Ulan-Ude, p. 194-196 (in Russian) [Яловик Л.И., Шелковникова Н.А., Татаринов А.В. Комплексные руды Юбилейного рудного поля (Муйский золоторудный район) // Минерагения Северо-Восточной Азии: Материалы II Всероссийской научно-практической конференции / Ред. Е.В. Кислов. Улан-Удэ: «Экос», 2011. C. 194-196].

Yatsenko A.S., 1995. Structural zonation of mineralization as exploration search criterion of the Irokinda gold deposit (Mid-Vitim highland). Izvestia VUZov. Geologiya i Razvedka (Geology and Exploration) (4), 73-79 (in Russian) [Яценко A.C. Структурная зональность оруденения как поисковый критерий на месторождении золота Ирокинда (Средне-Витимская горная страна) // Известия ВУЗов. Геология и разведка. 1995. № 4. С. 73-79].

Yatsenko A.S., 1998. The influence of the intra-ore tectonics on the distribution of gold in the flat-lying quartz veins of the Irokinda deposit. Izvestiya VUZov. Geologiya i Razvedka (Geology and Exploration) (4), 65-70 (in Russian) [Яценко А.С. Влияние внутрирудной тектоники на распределение золота в пологозалегающих кварцевых жилах месторождения Ирокинда // Известия ВУЗов. Геология и разведка. 1998. № 4. С. 65-70].

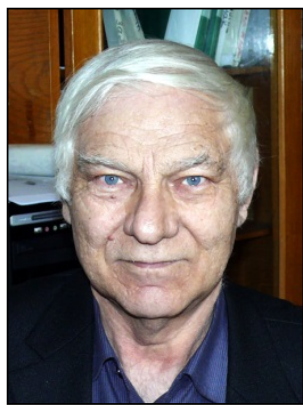

Татаринов Александр Васильевич, докт. геол.-мин. наук, г.н.с.

Геологический институт СО РАН

670047, Улан-Удэ, ул. Сахьяновой, 6а, Россия

e-mail: tatarinov@gin.bscnet.ru

Tatarinov, Aleksander V., Doctor of Geology and Mineralogy, Chief Researcher

Geological Institute, Siberian Branch of RAS

6a Sakhyanova street, Ulan-Ude 670047, Russia

e-mail: tatarinov@gin.bscnet.ru 
A.V. Tatarinov et al.: Spherical microparticles from gold-bearing quartz veins...

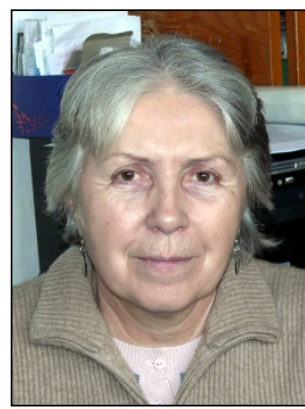

Яловик Любовь Ильинична, канд. геол.-мин. наук, с.н.с.

Геологический институт СО РАН

670047, Улан-Удэ, ул. Сахьяновой, 6а, Россия

e-mail: tatarinov@gin.bscnet.ru

Yalovik, Lyubov I., Candidate of Geology and Mineralogy, Senior Researcher Geological Institute, Siberian Branch of RAS

6a Sakhyanova street, Ulan-Ude 670047, Russia

e-mail: tatarinov@gin.bscnet.ru

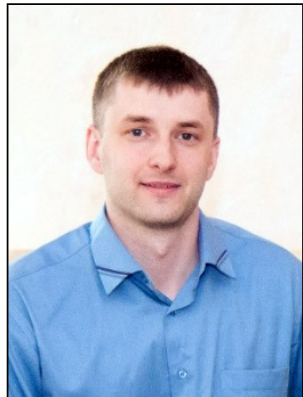

Ванин Вадим Александрович, канд. геол.-мин. наук

Институт земной коры СО РАН

664033, Иркутск, ул. Лермонтова, 128, Россия

e-mail: vanin_geo@mail.ru

Vanin, Vadim A., Candidate of Geology and Mineralogy

Institute of the Earth's Crust, Siberian Branch of RAS

128 Lermontov street, Irkutsk 664033, Russia

e-mail: vanin_geo@mail.ru 